\title{
Male Students at The University Endanger Academic Performance and Graduation To Endear Peers
}

\author{
Mettoh J. Hellen. \\ P.O. Box 1031-30300, Kapsabet, Kenya. 1. Kisilu M. Kitainge, P. O. Box 1125-30100,. Dept of tecnology \\ education, university of eldoret, Kenya
}

\begin{abstract}
The objective of this paper was to carry out an in-depth investigation into effects of peer influence on academic performance and graduation of male students from a university in Western region of Kenya. The study was given credence by poor academic performance and general lack of enthusiasm in learning among these male students. The theoretical foundation of this study was social learning theory. In this purposive constructivist research, the researcher sought to establish the meaning of the phenomenon that was particular and context-based from the views of the six study participants and the aim was not to generalize the findings. Views were collected by use of unstructured interviews and a journal was kept throughout the study. The data collected was analyzed thematically and the results were presented as reported by the respondents with the aid of thematic networks. The findings of this study showed that peers as claimed by the participants were found to be supportive, accomodative, tolerant and concerned. Parents could deny their sons whatever they needed but there was nothing that the participants could miss with peers being around. On the basis of the findings, it was recommended that male students ought to choose friends wisely to avoid engaging in negative peer pressure.
\end{abstract}

Keywords: Academic Performance, influence, Peers, Male students, University.

\section{INTRODUCTION}

This chapter comprises of the background of the study, statement of the problem, purpose of the study, objective of the study, research questions, significance of the study, assumptions of the study, limitations of the study and theoretical framework.

\subsection{Background of the study}

Education Year in Review (2012) supports the importance of education by arguing that the role of education in economic growth cannot be understated as it brings substantial benefits to people making its development imperative. Peer influence occurs when an individual experiences implied or expressed persuasion to adopt similar values, beliefs and goals or to participate in the same activities as those of the peer group (Oni, 2010). Wang' eri and Otanga (2013) point out that more boys than girls are influenced by peers to engage in all sorts of anti-social behaviours that include: engaging in sex, pornography and drugs that lead to negligence of academic work. According to (Regan \& Morrison, 2011) social identity theory suggests that a significant portion of an individual's self-concept is formed through their peer groups. Students who enter college determined to remain non-drinkers often give in to peer pressure in order to become part of the in-group (Borsari \& Carey, 2001). Therefore vulnerable college students like freshmen and non-drinkers will give in to peer pressure in the hope that they be accepted socially and have a successful transition from high school to college. Under Kremer and Levy (2003) preference model, a drinking roommate influence others into drinking and this result into poor study habits that lead to low academic performance.

\subsection{Statement of the problem}

A study carried out by the 'Association for the Development of Education in Africa-ADEA' (2003) indicates that there are a number of obstacles to high level of academic achievement. World Bank (2012) also appreciates that persistent campaign for awareness of girls' retention in schools has become a success at the expense of the boy child. This study focused on the male university students and it was preceeded by the researcher' $s$ interest on the boy-child.

\subsection{Purpose of the study}

This study aimed at investigating ways in which peer influence affects academic performance and graduation of male students from a university in Western region of Kenya.

1.4 Objective of the study

The study was informed by the following objective:

1. To examine how peer influence affects academic performance and graduation of male university students.

1.5 Research question

The question that guided this study was: 
1.How does peer influence affects academic performance and graduation of male university students?

\section{6 significance of the study}

The study makes male university students to choose friends wisely by avoiding those who influence negatively on issues of drugs and substance abuse. Kinard and Webster (2010) are in agreement with the argument that peers indeed are instrumental in influencing their colleques on issues partaining to drugs and substance abuse.

\subsection{Assumptions of the study}

The study assumed that the male students had concerns that made them not to perform as expected and therefore inhibiting them from graduating.

\subsection{Limitations of the study}

The participants of the study may not have had the willingness to disclose issues at hand.

\subsection{Theoretical framework}

Theoretical framework for this study was informed by Bandura' s social learning theory (Bandura, 2000). Social learning theory believes that human behaviour is socially transmitted either deliberately or inadvertently through the example provided by people whom we observe (Teklemariam, 2008).

\section{LITERATURE REVIEW}

\subsection{Overview}

This chapter gathers and gives a review of prior studies' findings that relate to the topic under study.

\subsection{Effects of peer influence on academic performance and graduation of male university students}

Oni (2010) posits that peer pressure is the influence that people in one' s age group exert on him bringing about changes in his attitudes, values or behaviours. Peers could also affect others' preferences. For example, seeing friends consume an addictive substance could act as a cue and stimulate desire for that substance (Laibson, 2001). Palai, Letshwiti and Maswabi (1999) cited in Maundeni (2004) assert that boys are pressured by peers to become sexually active. NACADA (2010) also argues that parents leave the youth without role models hence the youth opt to support one another. The aspect of peer pressure by male university students is also supported by Othero, Aduma and Opil (2009) who reveal differences between male and female students at Maseno University in their approaches to relationships and sex. In the study, while majority of male students share their sexual experience with their friends, female students discuss boy friends in groups influencing each other positively. Being sexually active and especially under the influence of friends means that peers will spend most of their time with girlfriends forgeting their academic work and this leads to poor academic performance. Madlala (2002) supports this arguement by revealing that while girls usually cite religious beliefs and mother as their greatest influence in life; boys choose peers. Peer pressure can be harmful by causing disruptions (Lazear, 2001), spread of diseases (Miguel \& Kremer, 2004) or the spread of information (Munshi \& Myaux, 2006). A student who is under the influence of peers is not dependent in making choices so that even if he goes to study at the library a friend will persude him to leave studies so as to take an outing.

Sharry (2004) asserts that peer pressure results in negative decisions since students are not cooperating and in the process lose a lot of time for their lessons which in turn results in poor academic performance. Maundeni (2004) argues that people who are under constant pressure from peer networks usually do not feel they have control over important aspects of their lives and they have low level of self-efficacy (Bandura, 1996) cited in (Maundeni, 2004). 'Marriage Unique Effects' (2002) also posit that, men today behave as boy-men. A male student who does not want to care about his academic work and desire to stay at the university for more than eight years has refused to mature. Kremer and Levy (2003) affirm that when a learner is isolated and rejected by his/her peers he/she may perform poorly academically. Buote (2001) agrees with this argument by asserting that learners who perform poorly in school are those most rejected by their peer groups in class.

This second section reviewed literature on peer influence on academic performance and graduation of male university students. The literature supports the argument that being under constant pressure from peer networks usually makes learners unable to have control over important aspects of their lives. The study went ahead to examine how peer influence affected academic performance and graduation of male students from a university in Western region of Kenya

\section{RESEARCH DESIGN AND METHODOLOGY}




\subsection{Overview}

This chapter deals with the following areas: Qualitative research approach, relativist ontology, constructivist epistemology, theoretical perspective, case study methodology, selection of participants, data collection instruments, ethical considerations and data analysis procedures and interpretations.

\subsection{Qualitative research approach}

This constructivist research sought to establish the views of the six study participants and the aim was not to generalize the findings. Richards (2009) posits that research can be subjective, particular and contextbased and need not necessarily be based on simple random samples and be generalisable. Qualitative research usually operates on the premise that total detachment on the part of the researcher is unattainable (even if deemed desirable) and that the individual who carries out research comprises an integral component of the entire process as opposed to being a disembodied bystander with the capacity to provide an ' uncontaminated' account (Horsburgh, 2003).

\subsection{Relativist ontology}

Ontologically the study applied relativist perspective. Richards (2003) holds that there is no single position or reality that is not dependent on human understanding and that people construct meanings and behaviour in different ways; hence different realities.

\subsection{Constructivist epistemology}

It was in line with this advice that the study engaged relativist ontology and constructivist epistemology because they both sought to construct knowledge about how male students at a university in Western region of Kenya perceive, interpret and understand issues that affect them in their contexts. Stacy and Miles (2007) on the other hand argue that epistemology modifies methodology.

\subsection{Theoretical perspective}

The theoretical perspective engaged in this study was phenomenology. If the web of the phenomena was not critically understood, people were bound to imagine that these male students failed to graduate merely because of poor academic performance yet nobody understood the logic behind this poor academic performance. It is this gap that this study sought to critically unearth so that knowledge is brought to light.

\subsection{Case study methodology}

The study adopted case study methodology and gathered information from the study participants through the use of unstructured interviews in agreement with case studies (Eriksson and Kovalainen, 2008). The researcher focused on intensive case study where the interest was to understand these unique cases at hand from the inside. Eriksson and Kovalainen (2008) contend that the aim of intensive case study research is to understand and explore the case from the 'inside' and develop understanding from the perspectives of the people involved.

\subsection{Selection of participants}

The researcher identified the participants based on the duration one had stayed at the university; the longer the duration the higher the chance of having been selected to participate in the study. The male hostels caretaker helped in identifying the participants.

\subsection{Data collection instruments}

The methods that were used to collect data were unstructured interviews and journal keeping. The reflective notes kept in the journal supplemented the data that was recorded.

\subsection{Ethical considerations}

Confidentiality and anonymity present challenges with qualitative designs due to qualitative research instruments which are mainly carried out on one to one basis and the narrative form of data to be collected (Creswell, 2009). The researcher made every effort to protect the identity of the participants and the institution where the research was carried out. Therefore, the name of the institution was not disclosed and pseudonyms were used for the case of the participants' names to conceal their identity. The researcher was also weary of close personal relationships that could develop between the participant and the researcher. The researcher did not encounter such a challenge and if any, could have recognized this and made referrals to appropriate professionals so as to ensure that the welfare of the participants took precedence over the goals of the study.

IV.

DATA ANALYSIS AND INTERPRETATION

\subsection{Overview}

In this chapter data is presented as generated from the 6 participants. The chapter also entails data analysis and interptretations guided and organised according to the objective of the study which was to examine how peer influence affects academic performance and graduation of male students from the university. AttrideStirling (2001) analytic technique called thematic analysis was adopted in this study. This process of data analysis involves reduction and exploration of the text.

\subsection{Analysis stage A: Reduction of the text}

Data on how peer influence affects academic performance and graduation was broken down.

\subsubsection{Step: 1 coding the collected data}


Data was broken down with the aid of the coding framework that was based on the salient issues that arose in the study as shown in Table 1.

Table 1: Presenting, dissecting codes and Identifying basic themes

\begin{tabular}{|c|c|c|}
\hline Codes & Dissected codes & Basic themes identified \\
\hline Help & $\begin{array}{l}\text { Assist } \\
\text { Support }\end{array}$ & $\begin{array}{l}\text { 1. Pastors who are roommates give both spiritual and } \\
\text { material support. }\end{array}$ \\
\hline sponsor & Aid & $\begin{array}{l}\text { 2. When there is lack of finances friends will always } \\
\text { come to aid their peers. }\end{array}$ \\
\hline behaviour & Character & $\begin{array}{l}\text { 3. Male students feel that it is fortunate to always have } \\
\text { friends who are of the same character as theirs } \\
\text { because they will always understand their needs for } \\
\text { example they can donate clothes to one who has sold } \\
\text { his to get money for drugs and substances. }\end{array}$ \\
\hline Comrades & $\begin{array}{l}\text { Friends } \\
\text { Buddies }\end{array}$ & $\begin{array}{l}\text { 4. Worst is when the friends are engaging in } \\
\text { irresponsible acts. } \\
\text { 5. Buddies invite each other to parties where alcohol } \\
\text { and marijuana are introduced free of charge }\end{array}$ \\
\hline Type & $\begin{array}{l}\text { Brand } \\
\text { Kind } \\
\text { Make }\end{array}$ & $\begin{array}{l}\text { 6. When one feels bad after taking a specific brand of } \\
\text { alcohol or drug, their friends will not advice them to } \\
\text { avoid such brands instead they will introduce them to } \\
\text { a different brand. This gives way to habits of hoping } \\
\text { from a brand of alcohol or drug to another. }\end{array}$ \\
\hline disturbance & $\begin{array}{l}\text { Frustrations } \\
\text { Stress }\end{array}$ & $\begin{array}{l}\text { 7. One accepts all the categories of friends after facing } \\
\text { frustrations from parents. }\end{array}$ \\
\hline Celebration & $\begin{array}{l}\text { Party } \\
\text { Bash }\end{array}$ & $\begin{array}{l}\text { 8. Friends can take you to attend parties and they meet } \\
\text { the expences. }\end{array}$ \\
\hline Enjoy & Relax & $\begin{array}{l}\text { 9. Peers spend a lot of time in surfing internet a lot } \\
\text { with friends to relax themselves after facing } \\
\text { disappointments from parents. }\end{array}$ \\
\hline Miss & Fail & $\begin{array}{l}\text { 10. A male student may fail to attend a lecture } \\
\text { because they feel sleepy after surfing the internet till } \\
\text { late at night with friends. }\end{array}$ \\
\hline Cause & Influence & $\begin{array}{l}\text { 11. Peers influence themselves into drinking so as to } \\
\text { forget their frustrations. }\end{array}$ \\
\hline Combrades & Friends & $\begin{array}{l}\text { 12. Peers give a treat to friends who are broke in the } \\
\text { most expensive hotels. }\end{array}$ \\
\hline
\end{tabular}

\section{1.2 Step 2: Identifying themes}

Themes were identified from the coded text to get basic themes, organizing themes and finally global theme as shown in Table 2.

Table 2: Themes abstracted from coded text segments for peer influence 


\begin{tabular}{|c|c|c|}
\hline $\begin{array}{l}\text { 1. Pastors who are roommates give both spiritual and } \\
\text { material support. }\end{array}$ & Supportive & Caring \\
\hline $\begin{array}{l}\text { 2. Peers will always come to ones aid, be it male or female } \\
\text { friends. }\end{array}$ & Supportive & Caring \\
\hline $\begin{array}{l}\text { 3. It is fortunate to have peers who are of the same character } \\
\text { and will always understand each other like donating clothes } \\
\text { when one has sold his to get money for drugs and } \\
\text { substances. }\end{array}$ & Accomodative & Caring \\
\hline 4. Peers introduce friends to alcohol for free & Accomodative & Caring \\
\hline $\begin{array}{l}\text { 2. Buddies invite their friends to parties and they do not } \\
\text { demand any money from them. }\end{array}$ & Concern & Caring \\
\hline $\begin{array}{l}\text { 6. When a friend feels bad after taking a specific brand of } \\
\text { alcohol or drug, peers will introduce to him a different } \\
\text { brand to cool him }\end{array}$ & Concern & Caring \\
\hline $\begin{array}{l}\text { 7. One accepts all the categories of friends after facing } \\
\text { frustrations from parents. }\end{array}$ & Accomodative & Caring \\
\hline 8. Peers can treat their friends at the most expensive hotels. & Tolerant & Caring \\
\hline $\begin{array}{l}\text { 9. Peers spend a lot of time in surfing internet a lot with } \\
\text { friends to relax themselves after facing disappointments } \\
\text { from parents. }\end{array}$ & Concern & Caring \\
\hline $\begin{array}{l}\text { 10. A male student may fail to attend a lecture because they } \\
\text { feel sleepy after surfing the internet till late at night with } \\
\text { friends. }\end{array}$ & Tolerant & Caring \\
\hline $\begin{array}{l}\text { 11. Peers influence themselves into drinking so as to forget } \\
\text { their frustrations. }\end{array}$ & Tolerant & Caring \\
\hline $\begin{array}{l}\text { 12. Peers give a treat to friends who are broke in the most } \\
\text { expensive hotels. }\end{array}$ & Supportive & Caring \\
\hline
\end{tabular}

\subsubsection{Step: 3 Construction of thematic networks}

The researcher arranged themes for how peer influence affects academic performance and graduation of male students from the university into: basic themes, organizing themes and finally came up with a global theme. This culminated into web-like networks refered to as thematic networks as shown in Figure 1. 


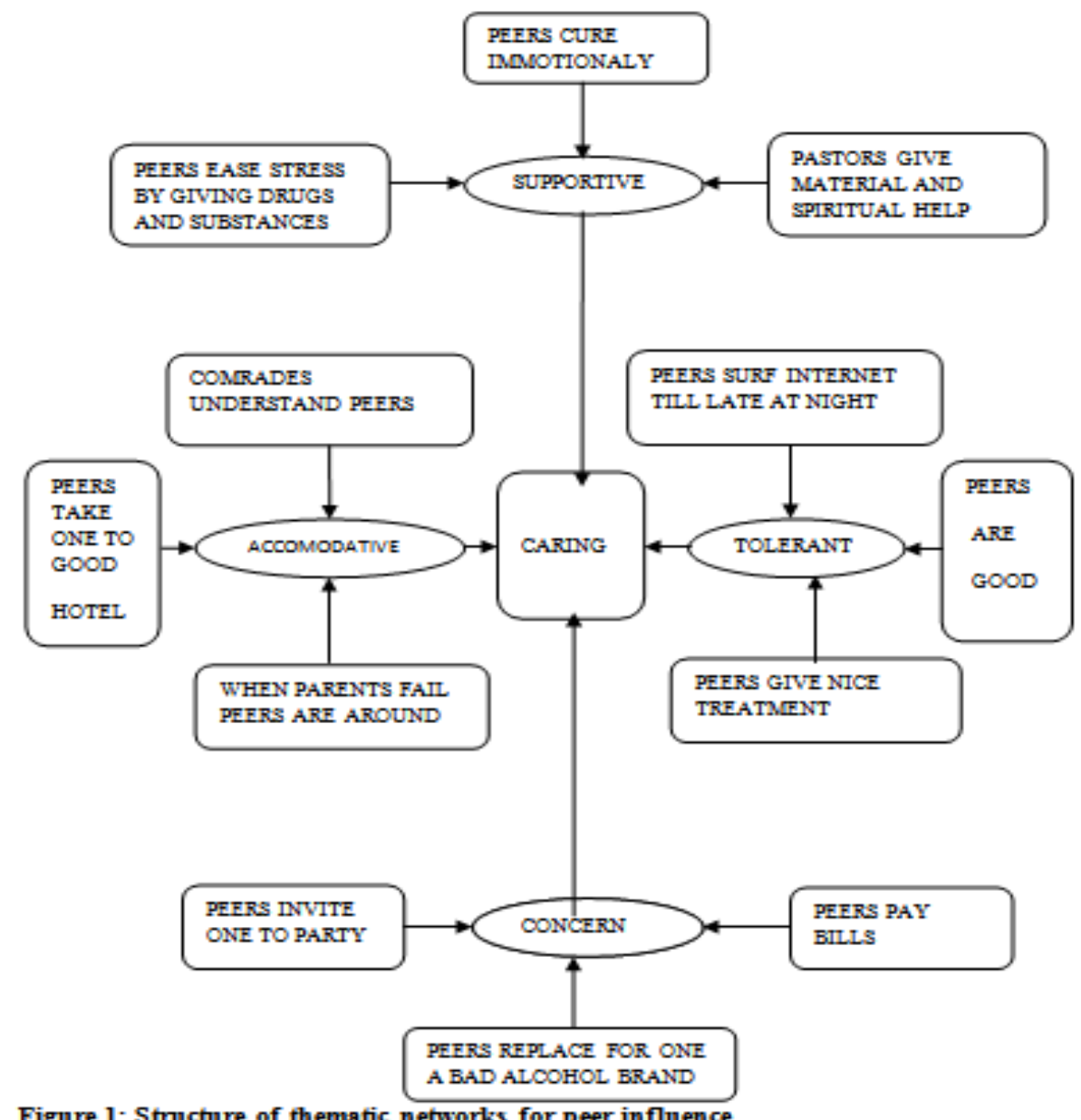

\subsection{Analysis stage B: Exploration of the text on peer influence}

Coded material yielded invaluable and rich information on peer influence on academic performance and graduation of male university students. The exploration of the text by the researcher entailed the description and interpretation of thematic networks.

\subsubsection{Step 4: Describing and interpreting thematic networks}

The researcher described and interpreted thematic networks alluding peers as caring as they were supportive, accomodative, concerned and tolerant.

\subsubsection{Peers were caring}

According to the male students, their peers were caring in the sense that they were supportive, accomodative, concerned and tolerant.

\subsection{Supportive}

The organizing theme for peers being supportive is backed by a lot of information from the interviews. According to these male students, the role of peers was seen as paramount especially where parental support was lacking as evident in the following excerpts.

Msema Yote: we need people...who associate with us, hata nikimwambia.. nililala kwa mtaro..atakuambia..hiyo ni kawaida (even if I tell him I slept in a ditch he will tell you, that is normal).. mummy utamwambia nililala kwa mtaro atakuambia wewe ni mbaya, unajua (if I tell mum that I slept in a ditch she will say I am bad, you see) ...infact that is the reason.. I keep on relapsing. No good support system... company of peers is therapeutic... since you come together in a bar.. matters affecting you... just like some people get therapy when they go to church...

McSmiler: My friends give me immotional support..surfing internet with me till late at night..ease my frustrations.

Rare Case: Theology students give me a lot of spiritual support.

Patikana: Parents fail to give enough pocket money.. approch the sober peers for financial support they refuse to.. they imagine you are going to use it on drugs and substances.. depressed.. only people who will come to you with sympathy will be the drug addicts..take you out for ' relaxation' which will be food, drugs and substances and of course women and you forget your studies...

DOI: $10.9790 / 0837-2107063140 \quad$ www.iosrjournals.org $\quad 36 \mid$ Page


From these excerpts, parents can deny their sons whatever they need but there is nothing that the participants can miss with peers being around. Madlala (2002) supports this argument by asserting that while girls usually cite religious beliefs and mother as their greatest influence; most boys nominate friends. NACADA (2010) argue that peer pressure that affect young people result from poor role models among the adults. The sober people, parents included have failed to offer positive support to these male students who are drug addicts making them to languish at the mercies of negative peer influence (excerpts from the researcher's journal, May $\left.21^{\text {th }}, 2015\right)$. Larimer et al (2005) also contend that among factors that expose students to drugs and substance abuse are personal independence, a lot of free time, making new friends and peer influence.

\subsection{Accomodative}

The organizing theme for peers being accomodative is backed by rich information from the interviews as follows.

Msema Yote: What can you lack with friends around madam?... peers will ensure you are always next to them... no matter what comes and... you indeed feel comfortable in their... company...however hard you try... not to relapse, peers force you to...as their company is wonderful... Comrades are the only people who... understand you and you socialise a lot with them...

Roho Safi: Peers will give...clothes after you sell yours.. drugs and substances when you cannot afford to buy them.. there is nothing good that the sober people can offer...just blame you.

Patikana: Friends will always take you...expensive hotels...entice you into substance abuse and relapsing becomes an order of the day.

Msema Yote: I was in an urban high school...peers introduced... smoking of marijuana and substance abuse... Peers... no better here...the cause of my relapsing is their company... However, peers are understanding... good company...help you forget problems...sober students hate interacting with drug addicts...only people around you...birds of the same feathers as you are...

McSmiler: When friends learn that you are frustrated and your spirit is down especially where parents have failed you, they will do whatever they can to cheer you up...

Msema Kweli: Friends come your way depending on your life style...Christian students...associate amongest themselves leaving you... drinking mates...your only companions.

The study found out that peers introduced the aspect of outings to their friends by sponsering them to " kill boredom' at the university. The same peers bought their colleagues what they needed including donating their personal effects like clothes (shirts and pair of trousers) to them after their friends sold theirs to maintain the habit of abusing drugs and substances. Maundeni (2004) argues that peer pressure lead to low level of selfefficacy. This subsequently interferes with academic performance and graduation.

\subsection{Peers were Concerned}

The organizing theme for peers showing concern is backed by enormous information from the interviews. To these participants, peers were the only ones who had the concern of teaching them the fastest modes of relieving stress and frustrations through drugs and substance abuse. For some this was a cause of relapse.

Msema Kweli: ... under substance abuse you cannot attend classes...

Patikana: Comrades..introduce alcohol and marijuana claiming...one becomes a hero. Besides, when you react.. specific brand of alcohol or drug.. introduce to you a different brand saying that it is better.. little do you realise the negative effects the drugs and substances are having.. academic performance.

Msema Yote: When you go out to relax with friends...especially when you are feeling low... intention is just to go and take a soda... you will find yourself.. on alcohol followed by marijuana... depending on who takes you out... However, peers are very good... even if they are taking you to the grave..least suspected since... a drug and alcohol addict...everybody runs away...even your family members... yet when you are feeling low, the only people who are concerned are peers...

Roho Safi: Friends will offer.. drug or substance you are in need of.. out to relax with them.. are the only people who can keep you company. Yaah..peer pressure... Peers could take friends to attend party at the most expensive hotels in the region by using profits from selling the stuff to these friends who are addicts (excerpt from the journal, May $\left.21^{\text {th }}, 2015\right)$.

Rare Case: Theology students ... support me.

McSmiler: The only people close..peers. We lock ourselves.. my room..play video games a lot.. till late... The study found out that parents took their children to what these parents perceived to have been the best university and schools and expected to get the highest level of success for them. Sentamu (2003) on the other hand argues that interactions in schools may lead to good or bad effects on students. Lazear (2001) also observes that peers could potentially affect others' choice sets for example through disruptions.

\subsection{Tolerant}

The organizing theme for peers being tolerant is backed by rich information from the interviews. Friends had a lot of empathy for their peers as they chose to be close to them as highlighted below. 
Patikana: I Surf internet a lot with friends.. facing disappointment from my parents..download for them computer games, notes and movies when they are out for lectures.

McSmiler: Friends are always with you. They cannot desert you.

Msema Yote: Each time my friends find me asleep... they will force me to accompany them.. local shopping center.. they will drink a lot...tempting me to join them even if I have no money... You talk a lot with them... you consult yourselves and share a lot of ideas...

The study noted the role of peers to have been very strong among the participants. Besides 'Marriage Unique Effects' (2002) contends that as singles within male or youth peer cultures, men today have plenty of time and opportunity to live the life of the boy-man in thoughts, habits and practices.

\subsection{Overview}

\section{DISCUSSION OF FINDINGS}

This chapter discusses findings on peer influence on academic performance and graduation of male students from the university.

\subsection{Discussion}

This study sought to investigate the effects of peer influence on academic performance and graduation. Peers were perceived to be very caring to the participants because they were supportive, accomodative, tolerant and concerned. They offered financial help to their friends; others offered material (shirts and pair of trousers) and spiritual support and also helped relieve stress through supply of drugs and substances. The participants were left with few choices to choose from and ironically friends who were always available were those who had issues also in their lives. The students who felt that they were okay could not come next to them and so the limited choices of friends made matters worse for these vulnerable male students.

The study also learnt that peers took their colleagues to the most expensive hotels in the region where they settled for them all forms of bills for being kind to them. Ironically, the same peers who were taking their colleagues for outings were themselves accusing their parents of giving them little pocket money and that they were engaging in businessess at the university. Under the preference model (Kremer \& Levy, 2003) having a drinking roommate as a first-year student could lead to more drinking which may lead to stronger taste for drinking as a second-year student. Besides, peers were tolerant because they surf the internet with their colleagues till late at night even when tired so long as they could relieve a frustrated friend besides giving nice treatment and being warm hearted. The behaviour of peers was quite unbecoming since while they attended classes, they left their frustrated friends to download for them computer games, notes, videos and movies. This happened when their friends were out for lectures. Sharry (2004) asserts that peer pressure results in negative decisions since students stop cooperating and in the process they lose a lot of time for their lessons which in turn results in poor academic performance.

While all these were happening among the peers, one important aspect of their university life was forgotten, this was the field of academic work which now crumbled down leading to poor academic performance and subsequent inability to graduate. The participants who had pastors as roommates confessed that those pastors gave them material support in form of money and were also handy in offering prayers and giving them spiritual guidance. Peers were extremely enticing and little could one get to know that he was fixing himself into a more frustrative web of students. The study also found out that a peer being concerned was the major cause of relapse that resulted from peer pressure where one was ever with friends who had never been to rehabilitation centres and so they heavily abused drugs and substances tempting others. The situation where the male students abused drugs and substances should not be taken for granted. These peers seemed to have been out to parties with a mission on unsuspecting friends who just accompany them to parties where there seemed to have been a lot of hidden agendas that came at the expense of their academic work.

Peers were found by the researcher to have played a big role in negatively influencing their friends on drugs and substance abuse in the name of "caring" where parents were found to be frustrating. Negative peer pressure ruins.

\subsection{Overview}

\section{CONCLUSION AND RECOMMENDATIONS}

This chapter presents conclusions and recommendations based on the findings on contextual concerns affecting academic performance and graduation of male students from a university in Western region of Kenya. Suggestions for further study have also been made.

\subsection{Conclusions}

The study found out that peer influence affected academic performance and hampered graduation of male university students.

6.1.1 Peer influence affected academic performance and hampered graduation of male university students 
The study noted peers to have played a big role in the life of their colleagues and especially where there was poor relationship with parents. Peers seemed to have been 'caring' since they were supportive, accomodative, tolerant and concerned. Peers were ever available for their friends. Critical analysis of the help that friends offered to their peers was negative as it involved feastings that culminated into drugs and substance abuse which also attracted irresponsible sexual behaviour.

This habit came with dire consequences on the part of the participants. Peers who seemed to be drug peddlers could be the ones who take innocent friends to parties. The aim could have been to introduce them into the web of drugs and substance abuse. These friends who imagined that their peers were kind could latter pay dearly through boosting the trade of the ' good peers.' Friends also give nice treatment and are warm hearted. All these came with a price because of being drunk, sick from STIs, over sleeping because of surfing internet till late at night and/or poor study habits. All these affected academic performance and graduation of male students from the university in Western region of Kenya.

\subsection{Recommendations}

On the basis of the findings of the study, the following recommendations were made.

1. Male students ought to choose friends wisely to avoid engaging in negative peer pressure.

2. Peers were not genuine friends as expected and male students ought to distance themselves from them since they have hidden agendas such as influencing on drugs and substance abuse.

\subsection{Suggestions for further research}

The results of this study offer the following implications for future research:

There is need to investigate the effects of the university regulations and routine on academic performance and graduation of male university students.

\section{ACKNOWLEDGEMENT}

I give honour and praise to God for his guidance and strenght throughout the writing of this thesis.I appreciate my family members for their unshaken believe in me, and for their moral and spiritual support. May he who sees in secret reward them openly. I extend my gratitude to my supervisors Dr K.M Kitainge and Dr. Rachel R. for constantly reading and patiently correcting my work. May God bless you. I thank the university of Eldoret for the opportunity given to me to study in the institution. I appreciate the Government officers for granting me authority to carry out this study. I give thanks to the university in Western region of Kenya for giving me the opportunity to carry out research in the institution. Special thanks go to the research participants for their willingness to share freely the information that I needed. May God shield you from the web of negative peer influence.

\section{STATEMENT OF COMPETING INTERESTS}

The authors have no competing interests.

\section{REFERENCES}

[1] Association for the Development of Education in Africa-ADEA. (2003). "The challenge of learning": Improving the quality of Basic Education in Sub-sahara Africa. ADEA discussion paper, in ADEA Biennial meeting, Grand Baie, Mauritius.

[2] Attride-stirling, J. (2001). Thematic Networks: An analytic tool for qualitative research; London: Sage Publications, vol. 1(3): 385-405. (2001) 1:3.

[3] Bandura, A. (2000). Exercise of human agency through collective efficacy. Current Directions in Psychological Science, 9, 75-78. (6).

[4] Borsari, B., \& Carey, K. B. (2001). Peer influences on college drinking. A review of the research. Journal of Substance Abuse, 13, 391-424.

[5] Buote, C. A. (2001). Relations of autonomy and relatedness to school functioning and psychological adjustment during adolescence. Dissertation. Humanities and Social Sciences, 62 (1).

[6] Creswell, J. W. (2009). Research design. Qualitative, quantitative and mixed methods approaches. $\left(3^{\text {rd }}\right.$ ed). London: Sage publications.

[7] Education Year in Review (2012). Available online from the World Bank website at: HYPERLINK"http://go.worldbank.org/BKIONOCMB0" http://go.worldbank.org/BKIONOCMB0

$<$ Accessed on 27 January 2016>

[8] Eriksson, P., \& Kovalainen, A. (2008). Qualitative methods in business research, London. Sage Publications Ltd.

[9] Horsburgh, D. (2003). Evaluation of qualitative research, Edinburgh, UK. Blackwell Publishing Ltd, Journal of Clinical Nursing, 12, 307-312. 
[10] Kinard, B., \& Webster, C. (2010). The effects of advertising, social influences, and self-efficacy on adolescence tobacco use and alcohol consumption. The Journal of Consumer Affairs, 44(1), 24-43. doi:10.1111/j.1745-6606.2010.01156.x.

[11] Kremer, M., \& Levy, D. (2003). “Peer Effects and Alcohol Use among College Students.” National Bureau of Economic Research Working Paper 9876.

[12] Laibson, D. (2001). “A Cue-Theory of Consumption.” Quarterly Journal of Economics, 116(1): 81- 119 .

[13] Lazear, E. (2001). “ Educational Production.” Quarterly Journal of Economics, 116(3), 777- 803.

[14] Larimer, M., Kilmer, J., \& Lee, C. (2005). College Student Drug Prevention: A Review of IndividuallyOriented Prevention Strategies. Journal of Drug Issues, 35, 431-456.

[15] Madlala, S.(2002). Youth, HIV/AIDS and the importance of sexual culture and context.

[16] 'Marriage Unique Effect'. (13 May 2002). Wall Street Journal .

[17] Maundeni, T. (2004). The Boy Child and HIV/AIDS in Btswana: A Neglected Issue in Research and Practice. Pula: Botswana Journal of African Studies Vol. 18 - no. 1

[18] Miguel, E., \& Kremer., M. (2004). “Worms: Identifying Impacts on Education and Health in the Presence of Treatment Externalities." Econometrica, 72(1): 159- 217.

[19] Munshi, K., \& Jacques M. (2006). “Social Norms and the Fertility Transition.” Journal of Development Economics 80(1): 138.

[20] NACADA, (2010): The role of parents in prevention and control of Alcohol and drug abuse among their children in Nairobi.

[21] Oni, A. (2010). Peer group pressure as a determinant of adolescent social adjustment in Nigerian schools. Asian Pacific Journal of Educators and Education, 25, 189- 202.

[22] Othero, D. M., Aduma, P., \& Opil, C. O. (2009). Knowledge, Attitudes and Sexual Practices of University Students for Advancing Peer HIV Education. East African Medical Journal Vol. 86, No. 1.

[23] Regan, D., \& Morrison, T. G. (2011). Development and validation of a scale measuring attitudes toward non drinkers. Substance Use and Misuse, 46, 580-590. doi:10.3109/10826084.2010.518748.

[24] Richards, K. (2003). Qualitative inquiry in TESOL. New York: Palgrave Macmillan.

[25] Richards, K. (2009). Trends in qualitative research in language teaching since 2000. Language teaching 42(2), 147-180.

[26] Sentamu, N. P. (2003). School' s influence of learning: A case of upper primary school in Kampala and Wakiso districts. Uganda Education Journal , 4.

[27] Sharry, J. (2004). Counseling Children, Adolescents, and Families. London: Sage publications.

[28] Stacy, M. C., \& Miles L. (2007). Qualitative Health Research.justifying knowledge, justifying methods, taking action: Epistemologies, Methodologies, and methods in qualitative research. 17:1316, DOI:10. 1177/1049732307306927: htt//qhr. sage pub. com/content/17/10/1316.

[29] Teklemariam, A. A. (2008). Developmental Psychology. A handbook for student- teachers, Nairobi: Publication department, Catholic University of Eastern Africa.

[30] Wang' eri, T. \& Otanga, F. H. (2013). Family, peer and protective factors related to sex behavior among urban adolescents in secondary schools in mombasa county, coast province, Kenya. International Journal of Education and Research Vol. 1 No. 5. pp. 1-16.

[31] World Bank (2012). Education Year in Review: Achieving Learning for All. July 2011 - June 2012. Washington, D.C.: The World Bank. Available Online at: http://siteresources.worldbank.org/EDUCATION/Resources/278200

1351884337891/Education_Year_in_Review.pdf <Accessed on 19 January2015. 